\title{
PEMBUATAN PERMEN JELLY MENGGUNAKAN UBI JALAR UNGU (Ipomoea batatas L.) DENGAN PENAMBAHAN BERBAGAI KONSENTRASI VIRGIN COCONUT OIL (VCO) DAN EMULSFIER TWEEN 80
}

\author{
THE MAKING OF JELLY CANDY USING PURPLE SWEET POTATO \\ (Ipomoea batatas L.) WITH THE ADDITION OF VARIOUS \\ CONCENTRATION OF VIRGIN COCONUT OIL AND TWEEN 80
}

\author{
Defrina Juliyanti ${ }^{1)}$, Moh. Su'i ${ }^{1)}$, Enny Sumaryati ${ }^{1)}$ and Suprihana ${ }^{1)}$ \\ 1) Fakultas Pertanian, Universitas Widyagama Malang \\ Email: defrina.cimuz1@gmail
}

\begin{abstract}
ABSTRAK
Penelitian ini bertujuan mengetahui pengaruh penambahan konsentrasi minyak kelapa murni (VCO) dan tween 80 terhadap karakteristik fisik, kimia, dan organoleptic permen jelly ubi jalar ungu. Penelitian ini menggunakan dua faktor yang disusun secara factorial. Faktor 1 yaitu penambahan Tween 80 dengan konsentrasi $4 \%, 6 \%$, dan $8 \%$ (b/berat total). Faktor 2 adalah penambahan VCO dengan konsentrasi 2\%, 4\% dan 6\% (b/berat total). Rancangan penelitian menggunakan Rancangan Acak Kelompok (RAK). Hasil penelitian menunjuk kan bahwa penambahan konsentrasi tween 80 dan VCO tidak memberikan interaksi yang berbeda nyata terhadap permen jelly umbi jalar ungu, namun dapat memberikan perbedaan yang nyata pada konsentrasi antar variable. Parameter yang memberikan perbedaan nyata terdapat pada analisa kadar air, total asam, rasa dan tekstur. Nilai perlakuan terbaik parameter fisik kimia dan organoleptik diperoleh dari penggunaan konsentrasi tween 80 sebesar $8 \%$ dan VCO sebesar $6 \%$. Sedangkan nilai parameter terbaik terdapat pada kadar air $(10,912 \%)$, total asam $(0,664 \%)$, rasa $(3,35)$ dan tekstur $(3,6)$.
\end{abstract}

Kata kunci : Permen Jelly, VCO dan Tween 80

\begin{abstract}
The aim of this research was to determine the effect of the concentration of virgin coconut oil and tween 80 on characteristics to the physicochemical and organoleptic jelly candy. This research used factorial Fully Randomized (FRD) method whith 2 factors The first factor was Tween 80 proportion which divided into 3 levels which were $4 \%, 6 \%$, dan $8 \%$ (w/total weight). Second factors was virgin coconut oil concentration which divided into 3 levels which were $2 \%, 4 \%$ dan $6 \%$ (w/total weight). The results showed that the addition of tween 80 and virgin coconut oil concentration did not give significantly different interactions to purple jelly candy, but gave a real difference in concentration of each variables. Parameters that provide real differences found in the analysis of water content, total acid, flavor and texture. The best results treatment of chemical and organoleptic physical parameters were obtained from the use concentration of $8 \%$ tween 80 and VCO by $6 \%$. While the best parameters were water content $(10.912 \%)$, total acid $(0.664 \%)$, taste $(3.35)$ and texture (3.6).
\end{abstract}

Keywords: Jelly candy, VCO and Tween 80 


\section{PENDAHULUAN}

Ubi jalar ungu telah banyak dimanfaatkan pada bidang industri terutama industri makanan dan telah memberikan aneka ragam produk unggulan daerah. Ubi jalar ungu mengandung oligosakarida dan antosianin. Oligosakarida diketahui mampu meningkatkan jumlah bakteri asam laktat dan juga menekan pertumbuhan bakteri Escherichia coli dalam feses (Suryadjaya, 2005).

Kandungan antosianin ubi jalar ungu memiliki aktivitas sebagai antioksidan (Budiman, 2003). Antosianin merupakan pigmen alami yang berpotensi memberikan warna alami sehingga menghasilkan penampilan yang menarik pada produk olahan Juanda dan Cahyono (2000).

Beberapa produk olahan dari ubi jalar ungu antara lain brownis, es krim, kukis, donat dan pasta. Diversifikasi produk dari ubi jalar ungu terus dikembangkan untuk meningkatkan daya guna hasil pertanian. Salah satu produk untuk mengembangkan hasil pertanian tersebut adalah pemanfaatan ubi jalar ungu dalam pembuatan permen jelly.

Virgin coconut oil atau virgin oil adalah minyak kelapa murni yang diproses dengan panas rendah atau tanpa panas dan tidak ada penambahan bahan kimia. Virgin oil sangat bermanfaat bagi kesehatan seperti menurunkan kolesterol (Nevin dan Rajamohan, 2004), mencegah penyakit jantung (Mary, 2004), diabetes milletus (Sircar dan Kansra, 1998) dan anti bakteri dan virus (Conrado, 2002).

Hasil penelitian menunjuk kan bahwa Medium Chain Trigliserida (MCTs) dalam minyak kelapa mampu membunuh Candida albicans, mampu memperbaiki metabolisme dan menambah ener gi. Virgin oil ini kaya akan asam laurat yang berperan sebagai anti bakteri dan anti virus. Ia juga digu nakan sebagai pengobatan AIDS. Dalam tubuh, asam laurat akan diubah menjadi monolaurin. Mono laurin adalah monogliserida dari asam laurat yang juga terdapat dalam susu ibu (Anonimous, 2004).

Dalam pembuatan permen jelly selain penambahan VCO diperlukan juga penambahan 
emulsifier untuk menjaga ukur, tanur, oven, desikator, cawan kestabilan permen jelly. Oleh karena itu penelitian ini dilakukan untuk mengetahui pengaruh perbandingan emulsifier dan VCO terhadap mutu permen jelly yang dihasilkan dan untuk mendapatkan formula terbaik (emulsifier: minyak VCO) dalam menghasilkan permen jelly dengan kenampakan dan flavor yang baik yang diterima oleh konsumen. Emulsifier yang digunakan dalam penelitian ini adalah tween 80 yang memiliki nilai HLB 15 yang sifatnya cenderung larut dalam air dan cocok dengan sistem emulsi "oil in water" (Belitz and Grosch, 1987).

\section{METODE PENELITIAN}

Penelitian dilakukan di laboratorium PT. Sorini Agro Asia, Jl. Surabaya Malang km 43, Pasuruan mulai bulan April 2016 Agustus 2016. Bahan utama yang digunakan adalah ubi jalar ungu yang diperoleh di Pasar Lawang. Alat-alat yang digunakan dalam proses pembuatan permen jelly adalah baskom, kompor gas, cetakan, thermometer, timbangan, pisau, saringan, sendok, gelas porselin, corong, Erlenmeyer, pipet volume, buret, gelas ukur, nampan, dan tissue.

Penelitian dilakukan secara faktorial dengan dua faktor yaitu faktor 1 : Tween 80 (T) dan faktor 2 : Minyak Kelapa Murni atau VCO (M). Faktor satu ada tiga level yaitu 4\%, 6\%, dan $8 \%$. (dari berat ICM). Faktor dua ada tiga level : $2 \%, 4 \%$ dan $6 \%$ (dari berat ICM), Penelitian menggu nakan Rancangan Acak Kelompok (RAK).

Data hasil penelitian di analisa menggunakan analisa ragam. Jika terdapat perbedaan kamudian dilanjutkan uji BNT.

\section{Pembuatan Permen Jelly Umbi Jalar Ungu \\ Disiapkan bahan-bahan dan} peralatan. Bahan-bahan ditimbang sesuai dengan jumlah yang dibutuhkan, yaitu ubi jalar ungu, $25 \%$ glukosa, $25 \%$ sukrosa, $3,5 \%$ karagenan, 2,5\% agar-agar, asam sitrat $1 \%$, air. Sedangkan Tween 80 dan VCO masing-masing bervariasi sesuai perlakuan.

Sari ubi jalar ungu dibuat dengan menghancurkan ubi jalar 
ungu dengan cara diblender dengan konsentrasi 1:3 (umbi : air). Setelah hancur, lalu saring hingga tersisa ampasnya. Didiam kan hingga filtratnya mengendap $( \pm 1-2$ jam $)$.

Seluruh sari ubi jalar ungu yang telah dipisahkan kemudian ditambahkan $25 \%$ glukosa dan $25 \%$ sukrosa lalu dipanaskan hingga suhu $100^{\circ} \mathrm{C}$. Selanjutnya ditambahkan 3,5\% karagenan dan 2,5\% agar-agar sambil diaduk hingga larutan mengental. Selanjutnya ditambahkan tween 80 dan VCO sesuai konsentrasi yang telah ditentukan dan diaduk hingga mendidih.

Setelah matang, ditambahkan asam sitrat $1 \%$ dan ditiriskan hingga uapnya hilang lalu disimpan dalam refrigerator selama 24 jam. Setelah membeku, dibiarkan pada suhu ruang selama \pm 1 jam lalu dilanjutkan dengan pengovenan pada suhu $80^{\circ} \mathrm{C}$ selama 8 jam. Setelah proses pengeringan selesai, permen jelly dapat dilakukan pengujian meliputi kadar air, uji daya lekat minyak, kadar abu, total asam, gula reduksi, warna, rasa, aroma, tekstur.

\section{HASIL DAN PEMBAHASAN}

\section{Kadar Air}

Berdasarkan data hasil penelitian, diketahui bahwa permen jelly ubi jalar ungu dengan penambahan konsentrasi Tween 80 dan VCO memiliki kadar air ratarata bekisar antara 10,91214,219\%. Kadar air tertinggi terdapat pada konsentrasi $4 \%$ Tween $80: 2 \%$ VCO, sedangkan nilai kadar air terendah terdapat pada konsentrasi $8 \%$ Tween 80 : $6 \%$ VCO.

Dari hasil analisis ragam diketahui bahwa konsentrasi Tween 80 dan VCO berpengaruh terhadap kadar air permen jelly umbi jalar ungu. Tetapi antara antara kedua factor tidak terjadi interaksi. Pengaruh penambahan Tween 80 dan VCO terhadap kadar air permen jelly umbi jalar ungu dapat dilihat pada Tabel 1 dan 2 .

Tabel 1. Rerata Kadar Air

\begin{tabular}{cc} 
Pengaruh & Tween 80 \\
\hline Tween 80 & Kadar air (\%) \\
\hline $8 \%$ & $11,381 \mathrm{a}$ \\
$6 \%$ & $13,182 \mathrm{~b}$ \\
$4 \%$ & $14,065 \mathrm{c}$ \\
\hline
\end{tabular}

Tabel 1 menunjukkan bahwa semakin tinggi penambahan 
konsentrasi Tween 80 maka kadar air semakin rendah. Konsentrasi tertinggi terdapat pada tween $4 \%$ sedangkan konsentrasi terendah terdapat pada Tween $8 \%$. Hal ini diduga karena Tween 80 bersifat sehingga mampu meningkatkan jumlah minyak yang terikat dalam permen jelly. Semakin banyak minyak yang terikat dalam minyak, maka secara relatif akan menurun kan jumlah air yang terdapat dalam permen jelly.

Tabel 2. Rerata Kadar Air Pengaruh VCO

\begin{tabular}{cc}
\hline Minyak VCO & Kadar air $(\%)$ \\
\hline $6 \%$ & $12,633 \mathrm{a}$ \\
$4 \%$ & $12,881 \mathrm{ab}$ \\
$2 \%$ & $13,114 \mathrm{~b}$ \\
\hline
\end{tabular}

Berdasarkan Tabel 2, sema kin tinggi konsentrasi VCO maka kadar air semakin rendah yaitu $12,63 \%$. Hal ini diduga karena semakin tinggi konsentrasi VCO maka dapat menurunkan jumlah air yang terdapat dalam permen jelly.

\section{Kadar Abu}

Berdasarkan data hasil penelitian, diketahui bahwa permen jelly umbi jalar ungu dengan penambahan Tween 80 dan VCO memiliki kadar abu rata-rata bekisar anatara 0,712 sampai 0,841\%. Kadar abu tertinggi terdapat pada kosentrasi $6 \%$ Tween 80 : 6\% VCO, sedangkan kadar abu terendah terdapat pada konsentrasi $4 \%$ Tween $80: 2 \%$ VCO.

Hasil analisis ragam menun jukkan bahwa konsentrasi Tween 80 dan minyak VCO tidak penga ruh terhadap kadar abu permen jelly umbi jalar ungu. Hal ini diduga dikarenakan penggunaan bahan baku yang memiliki kandungan mineral yang sama yaitu ubi jalar ungu dan karagenan.. Kadar abu permen jelly umbi jalar ungu masih memenuhi standart mutu SNI 3547.2-2008 yaitu di bawah 3\%.

Ubi jalar ungu mengandung kadar abu 0,84\% (Suprapti, 2003). Karagenan yang digunakan sebagai bahan penstabil juga menambah jumlah mineral dalam permen jelly yang dihasilkan. Menurut Winarno (1996), karagenan merupakan senyawa hidrokoloid yang terdiri atas ester kalium, natrium, magnesium dan kalium sulfat dengan galaktosa 3,6 anhidro galaktosa kopolimer. 


\section{Total Asam}

Total asam permen jelly umbi jalar ungu hasil penelitian didapatkan rata-rata total asam bekisar antara 0,389-0,664\%. Nilai total asam tertinggi terdapat pada konsentrasi $8 \%$ Tween $80: 2 \%$ VCO, sedangkan nilai total asam terendah terdapat pada konsentrasi $4 \%$ Tween $80: 6 \%$ VCO.

Hasil analisis ragam terhadap total asam permen jelly umbi jalar ungu menunjukkan bahwa konsentrasi Tween 80 dan VCO berpengaruh terhadap total asam. Namun faktor Tween 80 dan VCO tidak ada interaksi. Pengaruh penambahan konsentrasi Tween 80 dan VCO dapat dilihat pada tabel 3 dan 4 .

Tabel 3. Rerata Kadar Total Asam Pengaruh Tween 80

\begin{tabular}{cc}
\hline Tween 80 & Total Asam (\%) \\
\hline $4 \%$ & $0,433 \mathrm{a}$ \\
$6 \%$ & $0,545 \mathrm{~b}$ \\
$8 \%$ & $0,631 \mathrm{c}$ \\
\hline
\end{tabular}

Berdasarkan Tabel 3, semakin tinggi Tween 80 maka kadar total asam semakin tinggi juga, yaitu $0,631 \%$. Hal ini diduga karena Tween 80 memiliki pH yang cenderung netral sehingga dengan semakin meningkatnya konsentrasi
Tween 80 maka membuat total asam semakin meningkat, dimana total asam awal permen jelly sebelum ditambahkan tween 80 adalah $0,35 \%$.

Tabel 4. Rerata Kadar Total Asam Pengaruh VCO

\begin{tabular}{cc}
\hline Minyak VCO & Total Asam (\%) \\
\hline $6 \%$ VCO & $0,500 \mathrm{a}$ \\
$4 \%$ VCO & $0,535 \mathrm{~b}$ \\
$2 \%$ VCO & $0,573 \mathrm{c}$ \\
\hline
\end{tabular}

Tabel 4 menunjukkan bahwa semakin rendah konsentrasi VCO maka kadar total asam semakin tinggi. Hal ini terjadi karena semakin banyak jumlah asam lemak pada sistem emulsi maka jumlah $\mathrm{H}^{+}$yang terdisosiasi menjadi semakin besar. Hal ini berdampak pada semakin rendahnya kadar asam emulsi yang dihasilkan.

Smaoui dkk. (2012) mengatakan bahwa kandungan asam-asam lemak dalam VCO dapat menurunkan kadar asam emulsi. Penurunan kadar asam emulsi cenderung kecil, karena asam-asam lemak dalam VCO merupakan asam lemah sehingga hanya sebagian kecil yang terdisosiasi menjadi ion $\mathrm{H}^{+}$. 
Penurunan kadar asam juga kemungkinan disebabkan oleh kadar asam lemak bebas. Menurut Yati dan Nursal (2011), kadar asam lemak bebas dalam VCO adalah 0,2934\%, sehingga dengan konsentrasi VCO yang semakin meningkat maka meningkatkan kadar asam lemak bebas.

\section{Total Gula Reduksi}

Berdasarkan hasil penelitian, diketahui bahwa permen jelly umbi jalar ungu memiliki kadar gula reduksi bekisar antara 22,70 sampai $23,09 \%$ dan telah memenuhi standart mutu permen jelly (SNI 3547-2-2008) yaitu maksimal 25\%. Kadar gula reduksi tertinggi terdapat pada penambahan konsentrasi 8\% Tween : 6\% VCO, sedang kan kadar gula reduksi terendah terdapat pada konsentrasi 4\% Tween : 4\% VCO.

Hasil analisis ragam terhadap gula reduksi diketahui bahwa pemberian Tween 80 dan VCO tidak berpengaruh terhadap kadar gula reduksi permen jelly umbi jalar ungu. Hal ini diduga karena bahan baku sukrosa dan glukosa yang digunakan pada setiap perlakuan sama, sedangkan Tween 80 dan VCO yang ditambahkan tidak mempunyai kandungan gula reduksi.

Menurut Less dan Jackson (1999) kadar gula reduksi berkaitan dengan proses inversi sukrosa menjadi gula invert (glukosa dan fruktosa). Proses inversi akan terjadi karena adanya reaksi dari asam dan panas secara terpisah maupun dikombinasikan. Sukrosa dapat tereduksi menjadi glukosa dan fruktosa yang disebut gula reduksi karena adanya gugus $\mathrm{OH}$ bebas yang reaktif. Hal ini sesuai dengan pendapat Desrosier (1989) bahwa sukrosa bersifat non pereduksi karena tidak mempunyai gugus $\mathrm{OH}$ bebas yang reaktif. Selama pemasakan dengan adanya asam, sukrosa akan terhidrolisis menjadi gula invert yaitu fruktosa dan glukosa yang merupakan gula reduksi.

\section{Uji Daya Lekat Minyak}

Berdasarkan data hasil penelitian, diketahui bahwa permen jelly umbi jalar ungu dengan penambahan konsentrasi tween 80 dan VCO memiliki nilai uji 
pemisahan minyak rata-rata bekisar antara 2-4,76\%. Nilai uji pemisahan minyak tertinggi terdapat pada konsentrasi $4 \%$ Tween 80 : $6 \%$ VCO, sedangkan nilai uji pemisahan minyak terendah terda pat pada konsentrasi $8 \%$ Tween 80 : $2 \% \mathrm{VCO}$

Hasil analisis ragam diketahui bahwa tidak ada interaksi antara perlakuan konsentrasi tween 80 dan VCO terhadap daya lekat minyak. Konsentrasi tween 80 juga tidak berpengaruh terhadap daya lekat minyak. Sedangkan konsentrasi VCO berpengaruh terhadap daya lekat minyak. Perngaruh penambahan konsentrasi VCO dapat dilihat pada Tabel 5.

Tabel 5. Rerata Uji Daya Lekat Minyak Pengaruh Minyak VCO

\begin{tabular}{cc}
\hline Minyak VCO & Uii pemisahan \\
\hline $2 \%$ & $2,200 \mathrm{a}$ \\
$4 \%$ & $4,417 \mathrm{~b}$ \\
$6 \%$ & $4,620 \mathrm{~b}$ \\
\hline
\end{tabular}

Berdasarkan Tabel 5, pada konsentrasi $4 \%$ dan $6 \%$ rerata nilai daya lekat minyak $4,42 \%$ dan $4,62 \%$, sedangkan pada konsentrasi $2 \%$ rerata daya lekat minyak yaitu 2,2\%. Hal ini diduga terjadi karena semakin tinggi VCO maka kemampuan tween 80 untuk menyerap minyak VCO lebih sedikit sehingga VCO yang lepas dari emulsi semakin tinggi.

\section{Tingkat Kesukaan Rasa}

Rerata kesukaan panelis terhadap rasa permen jelly ubi jalar ungu dengan penambahan konsen trasi tween 80 dan minyak VCO bekisar antara 1,3-3,35 (sangat tidak suka-agak suka).

Skor tertinggi diperoleh dari perlakuan penambahan konsentrasi $4 \%$ Tween 80 : 2\% VCO yaitu sebesar 3,35 (agak suka). Sedangkan skor kesukaan panelis terendah diperoleh dari perlakuan penambahan konsentrasi $8 \%$ Tween 80 : 6\% VCO yaitu sebesar 1,3 (sangat tidak suka).

Perlakuan penambahan konsentrasi $8 \%$ tween 80 dan $6 \%$ VCO kurang disukai panelis karena rasa minyaknya masih terasa kuat sehingga panelis kurang menyukai. Sedangkan perlakuan penambahan konsentrasi $4 \%$ Tween 80 dan 2\% VCO lebih disukai karena rasa minyaknya tidak terlalu berasa. 
Rasa minyaknya yang masih kuat diduga dikarenakan masih adanya minyak yang belum terikat seluruhnya oleh tween 80, sehingga semakin banyak minyak yang ditambahkan dan semakin sedikit tween 80 yang mampu mengikat minyak maka rasa minyaknya akan semakin kuat.

\section{Tingkat Kesukaan Aroma}

Rerata skor kesukaan panelis terhadap aroma permen jelly umbi jalar ungu akibat variasi konsentrasi tween 80 dan VCO berkisar antara 2,5-2,8 yaitu antara tidak suka sampai netral.

Perlakuan penambahan konsentrasi $6 \%$ tween 80 dan $6 \%$ VCO memberikan skor tertinggi yakni 2,8 (netral) sedangkan perlakuan pada konsentrasi $6 \%$ Tween 80:2\% VCO dan $8 \%$ Tween 80:2\%VCO memiliki skor yang sama yaitu 2,5 (agak tidak suka).

Perlakuan 6\% Tween 80 : $6 \%$ VCO lebih disukai panelis karena dinilai memiliki aroma permen jelly yang tepat, sedangkan perlakuan penggunaan konsentrasi $6 \%$ Tween $80: 2 \%$ VCO dan $8 \%$
Tween : 2\% VCO dinilai belum memberikan aroma yang tepat.

\section{Tingkat Kesukaan warna}

Rerata kesukaan panelis terhadap warna permen jelly umbi jalar ungu dengan penambahan konsentrasi tween 80 dan minyak VCO antara 3,1 - 3,2 (Netral-agak suka).

Perlakuan penambahan kon sentrasi tween 80 dan minyak VCO 4\% Tween $80: 2 \%$ VCO, $4 \%$ Tween $80: 4 \%$ VCO, $8 \%$ VCO : 4\% Tween dan $8 \%$ Tween : $6 \%$ VCO memiliki skor tertinggi yang sama yaitu 3,2, sedangkan pada perlakuan 4\% Tween : 4\% VCO, $4 \%$ Tween $80: 6 \%$ VCO dan 6\% Tween 80: 6\% VCO memiliki skor terendah yaitu 3,1 .

Perlakuan penambahan tween 80 dan minyak VCO tidak berpengaruh terhadap warna permen jelly ubi jalar ungu. Hal ini karena minyak VCO dan tween 80 warnanya bening sehingga mempe ngaruhi warna permen jelly dan bahan baku utama yang digunakan sama yaitu umbi jalar ungu. 


\section{KESIMPULAN DAN SARAN}

\section{Kesimpulan}

Hasil penelitian menunjukkan bahwa tidak ada interaksi antar tween 80 dan VCO terhadap parameter mutu permen jelly ubi jalar ungu dalam penelitian ini. Namun penambahan tween 80 dan VCO masing-masing memberikan terhadap kadar air, total asam, rasa dan tekstur.

Nilai perlakuan terbaik parameter fisik kimia dan organoleptik diperoleh dari penggunaan konsentrasi tween 80 sebesar $8 \%$ dan VCO sebesar 6\%. Sedangkan nilai parameter terbaik terdapat pada kadar air $(10,912 \%)$, total asam $(0,664 \%)$, rasa $(3,35)$, dan tekstur $(3,6)$

\section{Saran}

Perlu dilakukan penelitian jenis emulsifier yang tepat untuk mengikat minyak kelapa murni (VCO) ke dalam permen jelly agar lebih optimal.

\section{DAFTAR PUSTAKA}

Anonimous. 2004. Is Virgin Oil Reaaly the Healthiest oil on Earth??.

http://www.theherbarie.com/ar chived-newsletters/2004-

October.pdf.

Blitz, H.D., W. Grosch, and P. Schieberle. 1987. Food Chemistry. Springer-Verlag Berlin Heidelberg. New York.

Budiman, I. 2003. Ubi Jalar Sweet Potato (Ipomoea batatas L. (Online). https://s3autums.wordpress.co m/ubi-jalar-sweet-potatoipomoea-batatas-l-lam/ (Tanggal Akses: 20 Juli 2016) Desrosier, N. W. 1988. Teknologi Pengawetan Maka nan. Penerjemah M. Muljo harjo.UI Press. Jakarta

Conrado, S. D. 2002. Coconut Oil in Health and Disease : Its and Monolaurin'S Potential as Cure for HIV/Aids, Cocotech Meeting XXXVII ${ }^{\text {th }}$, Chennai, India, July 25, 2002.

Juanda, D. dan B. Cahyono. 2000. Ubi jalar. Budidaya dan analisis usaha tani. Kanisius. 82 hal.

Mary, G. E. 2004. Coconut: In Support of Good Helth in the 21 st Century. htttp//: www.coconut oil. com.

Nevin, K. G. dan T. Rajamohan. 2004. Beneficial Effects of Virgin Coconut Oil on Lipid Parameters and in Vitro LDL Oxidation, Journal Clin. Biochem. September: 37 (9): 830-5.

Lees, R and E. B. Jackson. 2004. Sugar Confectionary and Chocolate Manufacture. 
Thomson Litho Ltd. East Kilbride, Scotland, 379.

Sircar, S. dan U. Kansra. 1998. Choice of Cooking Oils (myths and realities). Journal Indian Med. Assoc. 96 (10): 304-7.

Smaoui, S., H. B. Hlima, R. Jarraya, N. G. Kamoun, R. Ellouze, M. Damak. 2012. Cosmetic Emulsion of Virgin Coconut Oil: Formulation and Biophysical Evaluation. African Journal of Biotechnology 11(40): 9664-9671.

SNI No. 3547. 2-2008. Kembang Gula-Bagian 2 : Lunak. Badan Standartisasi Nasional. Jakarta

Suprapti, M.L. 2003. Tepung Umbi Jalar: Pembuatan dan Pemanfaatannya. Kanisius. Jakarta.

Suryadjaya, A. 2005. Potensi Umbi Jalar Putih dan Merah (Ipomoea batatas L.) untuk Pertumbuhan Bakteri Asam Laktat dan Menekan Pertumbuhan Pathogen. Skripsi. Fakultas Teknologi Pertanian. Institut Pertanian Bogor. Bogor.

Yati, K. dan F.K. Nursal. 2011. Formulasi Mikroemulsi Minyak Kelapa Murni (Virgin Coconut Oil) dengan Tween 80 sebagai Surfaktan. Laporan Hibah Penelitian. Fakultas Matematika Dan Ilmu Pengetahuan Alam, Universitas Muhammadiyah Prof. Dr. Hamka, Jakarta.

Thorpe, J.F. 1974. Thorpe's Dictionary of Applied
Chemistry. Longmans Greenand Company, London.

Winarno, F.G. 1996. Teknologi Pengolahan Rumput Laut. PT. Gramedia Pustaka Utama. Jakarta. 